\title{
Filmic constructions of the (religious) other: Laestadians, abnormality, and hegemony in contemporary scandinavian cinema
}

\author{
SOFIA SJÖ \& ANDREAS HÄGER \\ Åbo Akademi University
}

\begin{abstract}
Religious themes and characters have lately assumed center stage in a number of Scandinavian films. As with films from other parts of the world, so also in Scandinavian films a suspicion of certain religious traditions can be observed. In Scandinavian films this is not only true of traditionally foreign religions, but for some domestic religious groups as well, among them the Laestadian revival movement. In this article we analyze how this movement and its members are constructed as Other in four Scandinavian films. We theorize this 'Othering' with the help of Gramsci's concept of hegemony and argue that the 'othering' of Laestadians helps present the contrasting views as 'normal' and unproblematic. In the final section of the article we discuss the findings from the perspective of media and religion in a post-secular society, arguing that the media are today central to our understanding of religion, but at the same time shape religion in accordance with their own logics. We suggest that what is needed in order to understand how religion and groups such as the Laestadian revival movement are constructed in the media is religious media literacy.
\end{abstract}

Keywords: Scandinavian film, Laestadianism, Other, hegemony, religious media literacy

\section{Identifying difference}

An interest in religion is noticeable among many Scandinavian filmmakers. Several successful contemporary productions have dealt with religious themes and characters. Religion in Scandinavian film is no longer represented merely by some films by Ingmar Bergman or Carl Th. Dreyer - though these giants still inspire. Compared to Bergman and Dreyer, however, many contemporary filmmakers seem to have a more positive outlook on religion. Bergman's anti-clerical perspective is still prevalent, but many affirmative representations of religious characters are also found, and the attitude to 
religious experts is diverse (Daníelsson 2009). Nonetheless, a fairly obvious divide between an affirmatively constructed model of religion characterized by being open to change and to the needs of individuals, and a religion constructed as problematic and focused on power and rules, is easily recognizable (Sjö 2012; Sjö \& Daníelsson 2013). Though religious affiliation does not always determine how a character is portrayed in films, it is common in Scandinavian cinema, as in films from other parts of the world, to bestow certain religious characters with somewhat standardized functions in film narratives. This has inspired a number of studies and also provides the background for the present study.

Not all religious stereotypes are negative, and the portrayal of religious individuals has changed over time, but many problematic representations prevail. This is true, for example, of Hollywood productions, where Muslims, in particular, have often been allotted the role of bad guy (Sjö 2013). Historically, however, the representations in Scandinavian films have often been similarly condescending, and ethnic and religious minorities were long portrayed pejoratively (Wright 1998). Contemporary portrayals are more nuanced, but here too adverse stereotypes prevail. The young male religious fanatic, usually Muslim, is one such example (Tigervall 2003). In Scandinavian films of late, however, it is not just traditionally foreign religious groups that are sometimes constructed as a problem; the same is true for some domestic groups. The focus in this article is on one of these: the Laestadian revival movement.

Below we present four Nordic films with characters identified as Laestadians: Pahat pojat/Bad Boys, Populärmusikfrån Vittula/Popular Music, Kautokeino-opprøret/The Kautokeino Rebellion and Kielletty hedelmä/Forbidden Fruit. Our analytical approach is constructivist and our focus is on the strategies used in the films - narrative constructions, characterization, editing, visual effects etc. - to create a specific image of the Laestadian Movement. Theoretically we build on ideological studies of popular culture, arguing that what is striking in the representation of Laestadians in film is a clear 'othering' of members of the movement. We argue that Laestadians in the films studied are both directly and indirectly constructed as standing in sharp contrast to what is presented in the films as society at large. We theorize this 'othering' with the help of Antonio Gramsci's notion of hegemony, arguing that the 'othering' of Laestadians helps certain ideas and behaviors to come across as normal and unproblematic. In the final section we relate the findings to current understandings of a post-secular society, tying into debates about the role of media in shaping religion, which forms of religion are offered 
(media or other) space today, and the need of religious media literacy for a better comprehension of the role of religion in the media.

\section{Representing the Other}

Otherness and difference have always, consciously or unconsciously, interested filmmakers. This can be understood from several different theoretical perspectives. In short, thinking in terms of difference would seem to be typically human. We need difference to structure our world, and by representing the different as different we make sense of ourselves (Hall 1997). Thinking of some people as different and other to oneself can thus be argued to be in many ways natural, but this is not to say that it is unproblematic. In meeting the other, we easily turn to stereotypes. Though not all stereotypes are negative, stereotyping is still a question of ideology and power. As Richard Dyer has argued, stereotypes make the invisible visible and the unstable stable, drawing a clear line between them and us, making them the problem and us the norm (Dyer 1993, 11-18).

In contemporary society, the media have often been considered central to processes of 'othering.' Film has long been criticized for helping to support a certain view of the world and for its many negative representations of ethnic and sexual minorities in particular, but also of women and other 'others' excluded from what can be argued to be the traditional societal norm, that is to say, white, heterosexual men. Critics have pointed out the atrocities of past films and argued for alternative representations, but they have also exposed the less obvious ideology of more positive representations and discussed the need for a plurality of representations to counter hegemonic structures (see for example Friedman 1991; Thornham 1997). Research today is far from interested only in critiquing stereotypes in films, but rather in questioning what the various inclusions and exclusions suggest about current ideologies. However, as Jude Davies and Carol R. Smith $(1997,150)$ argue, in filmic representations the structuring paradigm of margins and center prevails, leading to someone always having to play the role of the Other, though this Other is nowadays perhaps more seldom represented through obviously one-sided stereotypes. The margins, in other words, clearly still fill a central symbolic function and are in many ways used to base and structure ideas of normality. In analyzing who ends up as the Other today, gender, ethnicity and sexuality are central. However, in much current research, religion too has been brought into the debate as a feature of both 'normality' and otherness (Sjö 2013). 
There are many theoretical perspectives that can be of use when approaching the subject of 'othering' in films. In discussing the 'othering' of people from the margins in Swedish films in relation to the center of Stockholm, Madeleine Eriksson (2010) has chosen to talk of internal 'othering' and internal orientalism, that is to say a form of discourse that leads to the stereotyping of people from the margins as more primitive, violent and uneducated, promoting by contrast the center. This is a process that, as we shall see, is taking place in the films discussed here too, but the theoretical base for this study has been more specifically inspired by Marcia Landy's (1994) work on film and politics and Paul Thomas' (2009) study of New Religious Movements in films. In their film analysis, both Landy and Thomas use Gramsci's theories and particularly his notion of hegemony. Gramsci argued that culture and religion legitimate and preserve the position of dominant groups in society: via culture and religion, a particular view of the world is presented as normal, and whatever is different is presented as abnormal, and in some sense wrong or even evil (Hoare \& Smith 1999). The Other is in other words used to underscore the views of the dominant classes. Regarding religion and film, Thomas (2009) argues that in the case of New Religious Movements in film we can see how these forms of religion are constructed as different and wrong in a way that presents more traditional religious ideas and values as unproblematically right. We in turn argue that in the films discussed here, the values associated with Laestadianism are to a large degree constructed as the problem, leading to the views held in the surrounding society coming across as unproblematic and taken for granted.

This study focuses on questions of ideology, stereotyping and power. However, it is worth pointing out that in film stereotypes that lead to 'othering' of some groups are also used for effect, and are then also, as Sharon Willis (1997) has illustrated, a question of esthetics. This is not to say that they are not simultaneously ideological, but their functions as markers of for example esthetic contrasts must not be overlooked. Here genre conventions enter the picture as an explanatory framework, a framework that is central to the films we will be discussing too.

\section{The Laestadian movement}

Before we turn to Laestadians on film a short introduction to the Laestadian movement is in order. The Laestadian movement takes its name from its founder, Lars Levi Laestadius (1800-1861), who worked as a pastor within the Lutheran church in the north of Sweden and among other things propa- 
gated abstinence from alcohol. The movement is most strongly represented in the Northern parts of Sweden, Norway and Finland, but also exists in for example North America. In Finland, at the turn of the millennium, the number of Laestadians was estimated to be approximately 175000 , or just over 3 per cent of the population (Talonen \& Harjutsalo 2001, 18). The Laestadian movement is a Lutheran revival movement, and its members in the Nordic countries to a large extent continue to belong to the national Lutheran churches, which makes estimations of how many belong to the movement difficult. Although Laestadians have largely kept their ties to the national Lutheran churches, they are in many ways a separate group, with their own meeting halls. It is a movement led by lay preachers, with a strong emphasis on the confession and forgiveness of sins (Wentin 1986).

The Laestadians are often, particularly in smaller communities, a very distinct group. People in the community know who belongs to the movement and who does not (Häger 2010). The Laestadians have a norm system which in some respects clashes with the majority. The temperance preached by Laestadius is still a central tenet of the movement. Other lifestyle aspects that are well known, to the point of cliché, are the high birthrate due to abstention from the use of contraceptives, and the critical view of the modern media and culture, particularly television. However, there is a recurrent perception from the outside not only that Laestadians often break these internal norms, but also that their young men in particular have a low regard for the rules of society at large (Suolinna \& Sinikara 1986, 145; Häger 2010). The distinct character of the Laestadian group makes them prone to prejudice, stereotyping and labeling in media discussions of the group (Ihonen 2000). The Laestadian group is thus often constructed as separate and marginal both in society and in the media. As we shall see, this is largely true for film as well.

\section{Bad Boys}

The Finnish film Bad Boys (Pahat pojat, Aleksi Mäkelä, 2003) is one of the most-seen Finnish films ever. In retrospect its popularity may seem somewhat surprising. The script was by many reviewers considered weak, and by today's standards the whole film seems rather simplistic. However, upon release, Bad Boys was something quite new in the Finnish context, with its use of the action genre format, fast editing and an emotionally charged score. The film is an action crime drama loosely based on real events. It tells of the criminal career of the four Takkunen brothers, who are in their 
teens and early twenties. The brothers start out small, end up attempting to break into a bank vault, and are finally charged with 94 robberies. Apart from the four brothers, the main characters are their father, Jouko, who is in a mental institution from which he escapes; Pirjo, the girlfriend of Eero, the youngest brother; and the chief of police, who is in charge of the investigation, and is also Pirjo's father.

The four brothers are in the film early on identified by other characters as Laestadians. They are from the start represented as very different from the surrounding society and from their peers regarding values and lifestyle. This is summarized by the headmaster of Eero's school who says that the brothers 'do not drink, do not swear, not even fight, but still you are always in trouble.' The youngest brother Eero is constantly bullied by kids at school who evidently identify him as other, but Eero refuses to fight back. Differences in sexual norms also become obvious in the depiction of Eero's and Pirjo's relationship. Eero is very uncertain of how to act around her in contrast to the other guys in school. However, the greatest conflict between the values of the brothers and of the surrounding society is the brothers' choice of a life as criminals, something which despite their strict upbringing they do not see as inherently wrong. It can be argued, however, that in the world of the film there does not seem to exist any unified system of values outside the brothers' family and religion.

Despite this, a line is obviously drawn in the film between the normal and the abnormal or the Other, where the Laestadians are placed in the latter category. This is done both directly and indirectly. Eero, in particular, repeatedly refers to a distinction between 'normal' and 'abnormal', and comments that he and his family are not 'normal'. When the brothers get electricity, once they are able to pay the bill, and have bought a television set, all for stolen money, one of the brothers comments that they are becoming like normal people, but the others claim that they have a long way to go. In another scene, Eero gets beaten up by Pirjo's former boyfriend and his friends. To his brothers, he acquits this with the statement that 'If I was normal, I would beat us up too'.

More indirectly, it is through the brothers' upbringing and the ideas and behavior of their father that Laestadians and Laestadianism are represented as Other. The brothers' father has forbidden the brothers to use violence, and this is why they do not fight back when attacked. However, the father does not think that the rules apply to him, and the film offers recurring scenes of the extreme violence the father inflicts on the boys. Though the film has a lot of comedic features, the scenes with the violent father use a 
visual language more familiar from horror films. For example, Jouko is in one scene portrayed from the point of view of one of the boys who is hiding under a bed, trying but failing to escape the monster that is his father.

An essential theme of the film and the way the film turns Laestadianism into something different is also money. Money seems to be the central value for the father, and he constantly tries to get money from his sons after he finds out about their criminal activities. Money also becomes a value in itself for the boys, which is emphasized in the recurring robbery scenes. The first scenes of the brothers successfully opening a safe is depicted in slow motion, accompanied with schmaltzy string music and the boys laughing happily at bills floating around in the air. These scenes also set the brothers' world apart visually. In several of the robbery scenes, the fast cutting used highlights the excitement and un-everydayness of the event, while the slow motion sequence also reinforces the idea that this is a different world. However, although the brothers in the film do not have a strong regard for the norms protecting property, both they and their father affirm the idea of pursuit of economic gain and the naturalness of being a member of consumer society.

The father-character in particular can be argued to normalize certain actions and to underline the difference between him and his faith in contrast to the rest of society. In short, Jouko takes everything to its extreme, making his actions much worse and unacceptable in contrast to other characters' choices, even when they are not that different. Eero's bullies beat him up, which is clearly represented as unacceptable behavior, but Jouko chases his children with a sickle, beats them till they bleed and kills their dog. Everyone wants money, but Jouko is so desperate to get it that he turns in his children to the police and gets himself blown up by mistake when hunting for the money he is convinced is hidden somewhere. Finally, Jouko's misogyny he is portrayed as beating his wife, and it is suggested that he might have killed her, calls her a whore when he visits her grave, and physically abuses a prostitute - makes every other attitude towards women, no matter how degrading, seem relatively harmless.

The actual depiction of religion in the film, that is to say depictions of actions and events that directly link to traditional religious themes, is quite simplistic and would mostly seem to have been included for effect. Laestadianism is mainly described as a set of rules - rules that the father character, said to be a preacher, does everything to break. In one scene, at his wife's grave, the father makes the sign of the cross, which suggests that the film makers were not greatly bothered to present an accurate representation of this form of religion, but rather used an element they recognized from Hol- 
lywood crime films. However, what is also noteworthy is how representing Laestadians as dysfunctional in many ways normalizes the rest of the world of the film. The image of Laestadianism in the film is thus not good, but the brothers do help balance the picture somewhat: they are mostly supportive of each other, yet this does not compensate for the extreme evilness of their father. Jouko is moreover not the only violent Laestadian father in Scandinavian cinema; a very similar character is shown in Popular Music.

\section{Popular Music}

The Swedish film Popular Music (Populärmusik från Vittula, Reza Bagher, 2004) is based on the best-selling novel by Mikael Niemi. Due to the popularity of the book, the film was eagerly awaited, and newspapers in both Sweden and Finland followed the filming process with great interest. The interest in Finland had a lot to do with the Finnish influence in the story and the many Finnish actors who had parts in the film. As with so many films based on books, the film did not live up to expectations, but was still quite successful commercially.

Popular Music is a coming-of-age story that follows two boys, Matti and Niila, from their first encounter as young children to their teenage years. As in many stories of this kind, being different is a recurrent theme, but the film also highlights the 'otherness' of the whole world of the film, in comparison to the rest of Sweden. Pajala in northern Sweden, where the story takes place, does not, as Matti puts it in voice-over, really seem to be a part of Sweden: their home has become a part of Sweden 'by chance. A northern appendage where there just happened to live people that only partly managed to be Swedish'. However, as the film begins, the rest of the world is slowly starting to influence Pajala too. The difference between Pajala and the rest of the world is part of the humor of the film. The theme of Laestadianism, on the other hand, is used to contrast the lives of the two main characters, and to explain the character development of Niila.

Both visually and narratively, Matti's and Niila's worlds are constructed as each other's opposites, with the good on one side and the bad on the other. Two scenes are particularly telling. In the first Matti is portrayed with his loud and laughing family, as they joke with each other and the parents hug lovingly. The setting for the scene, the family home, is full of light and colors. The soundtrack too is lively and highlights the warmth of Matti's family. In a scene soon after this, Matti goes to visit Niila. Whereas the scene in Matti's home was bright and joyful, the house Matti now enters 
is in shadow and completely silent, despite being full of children. Everyone seems to be on edge, and the reason for this tenseness is revealed when Niila's father Isak enters. When Niila's brother is caught doing something forbidden, the father takes him outside, and through the window Matti sees Isak beating his son until he bleeds, but without anyone, not even the boy being beaten, uttering a word. Both sound and mise-en-scène are thus used to contrast the worlds of Matti and Niila.

As with the Laestadian characters in Bad Boys, it is others who again identify these characters as Laestadian. In voice-over, Matti comments that Isak's form of Laestadianism is the worst there is, 'a Laestadianism without God.' This would suggest that there are also better kinds of Laestadianism, but these are not seen in the film: the only version of Laestadianism that the audience is offered is thus that of Niila and his family, with the brutal father again taking center stage. As is the case with the father in Bad Boys, Niila's father too is often presented using a visual language familiar from horror cinema, hovering threateningly over his children and pursuing them when they try to escape. Defining features for this frightening form of Laestadianism thus include having a large number of children and controlling them with religiously-motivated violence. In contrast, Matti's family - which has just two children, who are allowed a fair amount of freedom, and does not have much to do with religion - comes across as the ideal.

In terms of the relationship between the sexes, in Popular Music as in Bad Boys, Laestadianism is constructed as different and 'wrong.' Isak is not depicted as such a misogynist as the father in Bad Boys, but Niila's mother too appears oppressed and silenced. When Isak beats their children, for example, she does not react. The ideal, by contrast, becomes the relationship between Matti's parents, though this too is presented as traditional, with the mother doing the domestic work and the father providing for the family; since the Laestadian alternative is so much worse, however, the traditional structures in Matti's family do not come across as much of a problem.

As with the depiction of Laestadianism in Bad Boys, Laestadianism in Popular Music is very much played for effect. There is, in short, no interest in presenting a multidimensional portrait of the movement; instead the repulsive characteristics associated with the Laestadian characters are used to create contrast, and most importantly to create a drive for the character Niila to want to break free. Is Laestadianism, then, not granted any redeeming features in Popular Music? In a way, Laestadianism is allowed to bring 'salvation' to Niila. What makes Niila fight for a different life is his encounter with popular music. The first encounter comes when Niila 
trades the family Bible he was given by his grandmother on her deathbed for a music record. The first time Niila and Matti play the record, the room starts to spin, visually expressing the impact the music has on them. The symbolic word of God provided by Niila's grandmother is thus converted into the currency with which Niila purchases the insight into a different life.

Like the brothers' quest for money in Bad Boys, Niila's wish for a career in music can be read as an assent to the norms of a commercially and famedriven society. However, Niila's brutal upbringing makes his choice seem rational. This 'natural' need to break free of the constraints of Laestadianism, and to exchange the rural for the city, is also central in the following film to be discussed, Forbidden Fruit.

\section{Forbidden Fruit}

The Finnish film Forbidden Fruit (Kielletty hedelmä, Dome Karukoski 2009) is, like Popular Music, a coming-of-age story, but in contrast to the two previous films the focus in this film is on young women rather than on young men. Perhaps because of this, gender relations can be argued to be one of the keys to the story and the presented 'otherness' of Laestadians, but the film also includes many of the divisive aspects present in Bad Boys and Popular Music.

From the very beginning of Forbidden Fruit the main characters are identified as Laestadians. The film starts with two frames with information about the subcategory known as Old Laestadianism, giving the viewer a background about their beliefs and traditions, including what is forbidden in the movement - alcohol, popular music and premarital sex - and the group's annual meetings. Like the other films in this study, the world of Laestadianism in Forbidden Fruit is mainly constructed as rural. In both Bad Boys and Popular Music, the Laestadian families live in the countryside, in contrast to other characters who live in the more urbanized centers of the small communities portrayed. At the opening of Forbidden Fruit, we are introduced to Raakel and Maria and their life in a small village in Ostrobothnia in northwest Finland. Life in the village comes across as communal, but also divided. In the first scenes Raakel is shown getting out of bed, praying, and then waking up her twelve siblings and helping them with the morning routine. The following scenes take place in a crowded church, where a wedding is being celebrated. While the preacher talks about the sinfulness of the flesh, the girls are checking out the boys in the congregation. This pattern of a dichotomy between right and wrong, but also a challenge of this dichotomy, continues in the following scenes, when the bride's sister 
is refused entry to the wedding celebrations because of her way of life - it is revealed that she has broken with the community and chosen a different life in the city.

Laestadians in Forbidden Fruit are thus constructed as communal, but as a community with strong boundaries. The character of Maria is shown as longing to break through these boundaries, for a summer, and experience a different life. She therefore leaves the village for Helsinki, and Raakel is sent to guide her back. In the city, the contrast between Laestadians and others becomes even clearer. Not only are the two settings captured very differently, with the countryside presented as peaceful and close to nature, while with the use of faster cutting and more rhythmic music the city is given a much faster pace; in the city, the girls often seem quite simply 'lost'. They have no experience of alcohol, makeup or popular music, not to mention sex, and a local's description of a regular night out at a popular club - 'Get drunk, mess around with boys, dance, get pregnant, have an abortion. The usual' - is very disturbing, for Raakel at least.

At first, Forbidden Fruit seems to be built around a clash between two norm systems: the traditional life of the village and life in the city. While the traditional life of the village is governed by rules and norms, is structured around the community and focused on the avoidance of popular culture and, despite frequent references to sex, not giving in to bodily temptations, life in the city at first comes across as a form of freedom where the individual can thrive, popular culture rules, and sex is something everyday. It seems obvious that city life is to be regarded as the norm and the natural choice. However, in contrast to the two worlds of Matti and Niila in Popular Music, city life is not constructed in Forbidden Fruit as completely unproblematic. At first, everything seems exiting and new, and the elders' warnings seem irrelevant. However, with time darker aspects of city-life also appear, and particularly some scenes set at night introduce a sense of threat. Maria's experimentation with sex leads both women into trouble. When Maria finally decides to have sex for the first time, she is overcome by guilt and religious angst, illustrated visually with shadows on the wall that take the shape of the devil.

Maria's fate expresses a recognition that the wild life of the city is not in fact the ideal. Sex should not be seen as a sin, but that does not mean that the ideal is to sleep around. Popular culture is not dangerous, but not all of it is equally good. The community should not be allowed to regulate you, but that does not mean that you are better off alone. These are the insights and the side of city life that Raakel experiences, and which eventually emerge 
as the real ideal of the film. By accident, Raakel ends up in a movie theatre that is showing old black-and-white films and she is moved to tears. At the movie theatre she meets Toni, who introduces her to both alternative films and music. They slowly get to know each other, and when they finally have sex the act comes across as something positive, filmed in a bright space in contrast to the shadowy room where Maria loses her virginity. Raakel eventually returns with Maria to the village, where Maria gets married and Raakel tries to go back to her old life; but this she can no longer do, and finally decides to leave.

Raakel's choice to turn her back on village life, like Niila's departure in Popular Music, is presented in the film as a natural choice. The options seem to emerge as being between this or Raakel denying who she is, which would go against the theme of individuality in the film. Despite the fact that Raakel leaves, religion as such is not completely abandoned: Raakel does not give up her faith, she just breaks away from the strict regulations. For Laestadianism, however, this outcome is not positive: the movement comes across as controlling and judgmental. The gender dynamic is also problematized; although the male leaders in this film are far from the brutality of the fathers in Bad Boys and Popular Music, the Laestadian movement is clearly depicted as having abusive aspects. Maria's sister accuses her family of physical abuse, and the way the male leaders are often filmed from a high angle and portrayed as looming over the young women and pressing them to do as the movement wishes does not allow for a positive reading.

On the other hand, although the girls come across as somewhat damaged due to their upbringing in the community, Laestadianism is not constructed here as thoroughly evil. The world of the movement is constructed in ways that do not fit with contemporary society, but it does come across as an option for some who cannot handle this society. Though the members are often represented as judgmental, they are also recognized as wanting what they see as best for their own.

\section{The Kautokeino Rebellion}

In the Norwegian director Nils Gaup's The Kautokeino Rebellion (Kautokeinoopproret, 2008) we at first glance come across quite a different image of Laestadianism from that in the films analyzed above. This film is based on a Sami rebellion which occurred in the town of Kautokeino, Norwegian Lapland, in 1852, and making a film based on the event was long a dream of the director, himself a Sami from the region. This incident has been a 
very sensitive subject in the Sami community, and arouses questions both of guilt and of injustice. The Kautokeino Rebellion awakened a long overdue discussion of the event and the treatment of the Sami at that time. The film was well received, not least in Norway, and the importance of telling the story has been widely acknowledged. As Cato Christensen and Siv Ellen Kraft (2011) have shown, many religious themes and dimensions are present in the film. Gaup presents a religious revival inspired by Laestadius as the trigger behind the tragic events of the uprising, whose driving force for the Sami is not rebellion, but the hope for change in their social and economic situation.

The Kautokeino Rebellion has a fairly classical structure and feels very much like a western set in the north. As in the traditional western, the story is built around a clear dichotomy. On one side we have the Sami (or the natives) led by the young woman Elen. The Sami wish to be rid of the merchants who have driven many of the men into alcoholism and financial trouble; and inspired by the teachings of Laestadius they break with both the merchants and the official Norwegian Lutheran church. On the other side we find the merchants (the settlers), represented by the Swede Ruth, and the official church, represented by the pastor Stockfleth, who is sent to guide the Sami back to the store and the Church. The main struggle is between Elen and Stockfleth, who are represented as mutual opposites: woman vs. man, young vs. old, Sami vs. Norwegian, insider vs. outsider. The worlds they represent are also constructed as opposites, even though they are both religious: revivalism vs. official church, community vs. hierarchy, spirit vs. law.

For a long time, the official Norwegian account of the rebellion in Kautokeino put the blame on the revival movement. However, in Gaup's version of the events, blame is placed instead on the church and the state, and this has nowadays generally been accepted as a more honest reading. The religion practiced by the official church causes serious personal and social conflicts, whereas the Laestadian revival is seen as strengthening the Sami and offering them hope. In this film, then the hegemonic stereotypes are in several ways reversed. The Lutheran pastor is represented as a violent hypocrite, while the Laestadians are constructed as true believers, whose social action is not only communal, but also women-centered, with a female leader.

There are several different dimensions to this very different representation of Laestadianism. As Christensen and Kraft (2011) argue, Gaup's goal was to present what he saw as a more honest version of the historical events. 
It was also in his interest to make a film that portrayed Laestadians positively, because of the influence this group still has in the region. His portrayal highlights the positive influence of the movement at the time, particularly in relation to alcohol. What is noteworthy, however, is the way that here too the Laestadian movement becomes something exotic and Other, at least when one comes to the film from a non-Sami perspective, and indeed no doubt partly from a modern Sami perspective too. The audience can easily identify with the Sami, but the Sami and their beliefs are at the same time represented in a way that, as Christensen and Kraft (2011) argue, links them with ideas of a universal native spirituality where nature plays a major part. The Sami are depicted reading texts by Laestadius, but their spirituality is for the most part constructed visually and in a way that incorporates many aspects other than traditional Christian ones. Several scenes offer views of the vast, majestic landscape of Northern Norway provides the backdrop to many of the Sami's religious meetings, giving a nature-driven character to their spirituality.

Though the spirituality presented in the film no doubt speaks to many modern viewers, it is nonetheless represented as disconnected from the world at large. In contrast with the tragic events that follow, the scenes of the emerging spiritual movement seem almost dreamlike, set as they are in an idealized summer landscape. It is also a spirituality that is not allowed to survive. The responsibility for this is placed in the film on Stockfleth's brutally-constructed official Lutheranism, but the ideal would not really seem to be the religion offered by the Sami Laestadians either. Again, some kind of a middle way comes across as the norm. This middle way is defined by a young bishop who comes on a visitation, and who tries to help the Sami. The bishop is portrayed as sympathetic to the Sami, and aware of their problems. He emphasizes that it is important that religious and secular interests should not be mixed, something he accuses Stockfleth of doing. The ideal religion would thus seem to be a private religion that can help and support those in need but does not take sides.

\section{Dealing with difference}

To summarize, as we read the films studied here, the films all construct Laestadianism and Laestadians as in some sense different and Other. Laestadians are repeatedly represented as guided by norms and as focused on community. These norms and communities seem to offer what some characters need, and in this sense constitute an asset. However, several members of the 
movement, particularly those who exercise authority, are also represented as violent, abusive, and hypocritical, while others are seen as controlled, beaten and subjugated. With the exception of the Laestadianism presented in The Kautokeino Rebellion, Laestadianism is never represented as a sensible choice, and even in The Kautokeino Rebellion, Laestadianism comes across as in many ways different, connected as it is to an ethnic minority and Sami indigenous spirituality.

Four films can of course not on their own be argued to represent a general view of Laestadians. However, the way the films tie into representations of Laestadians in other contemporary media suggest that these films do capture a widespread perception. As Laestadians are a relatively distinct group in Finnish and Scandinavian society, they get their fair share of media exposure. In his overview of the media coverage of Laestadianism, Markku Ihonen (2000) notes that in the Finnish media Laestadianism is regularly depicted as something strange, and the same clichés - for example regarding large families - are often repeated. One example of recent news media coverage has been the extensive and ongoing discussion of sexual abuse of children in the Laestadian movement (Häger forthcoming). One novel about Laestadianism worth mentioning is Hannu Raittila's Ei minulta mitään puutu (['I shall not want', 1998) which tells of a Laestadian Summer Meeting (the Summer Meetings are a very characteristic and central feature of the Laestadian and other Scandinavian revival movements).

Taken together, we argue, that these representations highlight a hegemonic Scandinavian view of how life should be lived and what religion should look like. According to this view, the individual in many ways comes first, and communities, though not evil as such, should be there to support individuals, not to impose restrictions. Religion should be restricted to the private sphere, while secular values should guide life more generally. Focusing on love relationships and a professional career consequently emerges as the right thing to do.

Seen from the perspective of an academic understanding of religion today, it is not surprising that a religion represented as strongly governed by norms and a focus on community is constructed as problematic, while a religion focusing on the individual and not trying to restrict comes across as the ideal. It has often been argued that religion today is becoming more and more individualized; that is to say, it is seen as something that should be shaped in accordance with the needs of the individual. As among others Gordon Lynch (2007) and Sofia Sjö (2012) have argued, this is the form of religion we often encounter in films, and such a religion is often represented 
in a positive way. However, where this construction of religion is given credence, this entails, arguing from the theoretical perspective of hegemony, that those that do not fit in will become the Other and the problematic. When these processes take place in a medium such as film, religious representatives have very little to say in the matter, and the representations are instead guided by the interests of the media.

Building on Jürgen Habermas' theorizing (2008), contemporary Scandinavian society has been argued to be post-secular (Moberg \& Sjö 2012). This entails that religion is again considered to be on the agenda, as something that must be taken seriously for a thorough understanding of society. The 'post-secular turn' does not imply greater numbers of people identifying as religious, but it does point to a renewed awareness of religion and to some extent a greater religious presence in the public sphere. As several studies have argued, it is via media and popular culture that we can see the post-secular turn taking place (see for example Moberg \& Granholm 2012). In other words, the media are central to the renewed interest in religion. However, this also means that much of the religion we encounter in contemporary society is mediatized, or shaped according to the needs and interest of the media (Hjarvard 2013). This is also true for the representations of religion we have studied here, which are constructed in accordance with the logics of the film medium. Our study further highlights a central aspect of religion in a possibly post-secular Scandinavian society: an interest in religion does not imply a noncritical acceptance of all forms of religion; on the contrary, it would seem to entail an obvious 'othering' of those forms of religion that do not fit the norm. Despite the interest in religion in these films, and the post-secular turn in society more widely, the films studied support the notion that the hegemony today is still predominantly secular (Casanova 2009), and that religion overall will therefore always be questioned, but some forms more so than others.

Building on the current discussion of a renewed awareness and interest in religion, Michelle Dillon has posed the central question whether our post-secular society can deal with religious difference. She argues that the answer to a large degree is No (Dillon 2010). The films studied here point in the same direction, and illustrate that even a domestic religious tradition can be constructed as different and problematic. Even when films are made which incorporate a serious interest in religion, this does not displace the secular worldview and a default perception of religion as Other. Looked at over time, Scandinavian filmmakers are perhaps attempting to build a better understanding of Laestadianism, but negative stereotypes still prevail, 
and filmmakers continue to represent those who choose a more traditional religious worldview as Other. While the filmmakers' aim is probably not to take an ideological stand, but to tell an intriguing story, the political side of representation and the perhaps unintentional processes of 'othering' still lead to the films offering an ideological perspective.

One could argue that what is needed is that if we really want a society that is open to religious difference, both viewers and producers of films need to demand different stories and allow for different representations. However, this is to simplify the notion of how hegemony works and the power relations involved in representations. It is not easy to challenge what is taken for granted and constantly presented as the norm. What might help us better identify these processes of 'othering', and understand the construction of the Other in the media at large, is greater media literacy, and more specifically a religious media literacy (Graham 2012; Lövheim 2012). Religious media literacy offers an understanding of how the media work in relation to religion; among other things, this means recognizing the fact that not all religions interest media equally, and that religion in the media is always constructed with media-driven needs in mind. A post-secular mediatized society is thus a society where the need to understand who sets the agenda and why is vital.

In the case of Laestadianism in film, religious media literacy could enable recognition of the way movements such as this are constructed to meet the needs of the film medium to tell an intriguing story, and realizing that filmic representations, though they might not be entirely untrue, are always in some sense constrained by what is demanded by genre and narrative. If one wants to tell a story about growing up and breaking free, a religion that binds works a lot better than a religion that promotes the individual, whether this is an honest representation of the religion in question or not. This recognition could in turn suggest that in order to achieve an adequate understanding of religion in general or certain religious groups in particular, we need to look for alternative perspectives and voices, but it therefore also entails taking the media seriously when trying to fully understand prevailing views on religion today.

SOFIA SJÖ, Dr. theol., is a University Teacher at the Department of Comparative Religion at Åbo Akademi University, Finland. E-mail: sofia.sjo@abo.fi.

ANDREAS HÄGER is University Lecturer at the Department of Sociology at Åbo Akademi university, Turku, Finland. E-mail: ahager@abo.fi 


\section{Bibliography}

\section{Motion pictures}

Kautokeino-opprøret/ The Kautokeino Rebellion, dir. Nils Gaup. Norway, Rubicon Film, 2008.

Kielletty hedelmäl Forbidden Fruit, dir. Dome Karukoski. Finland, Helsinkifilmi, 2009.

Pahat pojat/ Bad Boys, dir. Aleksi Mäkelä. Finland, Solar Films, 2003.

Populärmusikfrån Vittula/ Popular Music, dir. Reza Bagher. Sweden/Finland/ Denmark, Happy End Filmproductions, 2004.

\section{Literature}

Casanova, José

2009 The secular and secularisms. - Social Research 74(4), 1049-66.

\section{Christensen, Cato \& Siv Ellen Kraft}

2011 Religion i Kautokeino-opprøret: en analyse av samisk urfolksspiritualitet. - Nytt Norsk Tidsskrift 1, 18-27.

\section{Daníelsson, Árni Svanur}

2009 From State Officials to Teddy Bears: A Study of the Image of Pastors in Selected Nordic Films. - Studies in World Christianity 15 (2), 162-75.

\section{Davies, Jude \& Carol R. Smith}

1997 Gender, Ethnicity and Sexuality in Contemporary American Film. Edinburgh: Keele University Press.

\section{Dillon, Michele}

2010 Can Post-Secular Society Tolerate Religious Difference? - Sociology of Religion 71 (2), 139-56.

\section{Dyer, Richard}

1993 The Matter of Images: Essays on Representations. London: Routledge.

\section{Eriksson, Madeleine}

2010 'People in Stockholm are smarter than countryside folks'. Reproducing urban and rural imaginaries in film and life. - Journal of Rural Studies 26, 95-104.

\section{Friedman, Lester D.}

1991 Unspeakable Images: Ethnicity and the American Cinema. Urbana: University of Illinois.

\section{Graham, Elaine}

2012 Religious Literacy and Public Service Broadcasting: Introducing a Research Area. - Gordon Lynch \& Joulyon Mitchell (eds), Religion, Media and Culture: A Reader, 228-35. London: Routledge. 


\section{Habermas, Jürgen}

2008 Notes on Post-Secular Society. - New Perspectives Quarterly Fall, 17-29.

Hall, Stuart

1997 The Spectacle of the 'Other'. - Stuart Hall (ed), Representation: Cultural Representations and Signifying Practices, 223-90. London: Sage Publications.

Hjarvard, Stig

2013 The Mediatization of Culture and Society. London: Routledge.

Hoare, Quentin \& Geoffrey Nowell Smith (eds and trans)

1999 Selections from the Prison Notebooks of Antonio Gramsci. London: Elec Book.

\section{Häger, Andreas}

2010 A religious group in its local society: A Finnish case study. Paper presented in RC 22, at the 17th ISA congress, 11-17 July, in Göteborg, Sweden

(forthcoming) Media, religion och skandal: Mediediskussionen om laestadianism och pedofili. Åbo: Ảbo Akademi.

\section{Ihonen, Markku}

2000 Mediakummajainen? Herätysliikkeen julkisuusongelmien äärellä. Tiedotustutkimus 4/2000, 68-78.

\section{Landy, Marica}

1994 Film, Politics and Gramsci. Minneapolis: University of Minnesota Press.

\section{Lynch, Gordon}

2007 Film and the Subjective Turn: How the Sociology of Religion Can Contribute to Theological Readings of Film. - Robert K. Johnson (ed), Reframing Theology and Film New Focus for an Emerging Discipline, 109-25. Grand Rapids: Baker Academic.

\section{Lövheim, Mia}

2012 Religious Socialization in a Media Age. - Nordic Journal of Religion and Society 25 (2), 151-68.

\section{Moberg, Marcus \& Kennet Granholm}

2012 The Concept of the Post-Secular and the Contemporary Nexus between Religion, Media, Popular Culture, and Consumer Culture. - Peter Nynäs, Terhi Utriainen \& Mika Lassander (eds), Post-Secular Society, 95-128. New Brunswick: Transaction Publishers.

\section{Moberg, Marcus \& Sofia Sjö}

2012 The Evangelical Lutheran Church and the Media in Post-Secular Finland. - Stig Hjarvard \& Mia Lövhem (eds), The Evangelical Lutheran 
Church and the Media in Post-Secular Finland, 79-91. Gothenburg: Nordicom.

\section{Raittila, Hannu}

1998 Ei minulta mitään puutu. Borgå: WSOY.

\section{Sjö, Sofia}

2012 Bad religion/Good spirituality? Explorations of Religion in Contemporary Scandinavian Films. - Journal of Scandinavian Cinema 2 (1), 33-46.

2013 Go with Peace Jamil - Affirmation and Challenge of the Image of the Muslim Man. - Journal of Religion and Film 17 (2), 1-31. Available at $<$ http://digitalcommons.unomaha.edu/jrf/vol17/iss2/8>

\section{Sjö, Sofia \& Árni Svanur Daníelsson}

2013 Detraditionalization, Diversity, and Mediatization: Explorations of Religion in Nordic Films. - Nordic Journal of Religion and Society 26 (1), 45-62.

\section{Suolinna, Kirsti \& Kaisa Sinikara}

1986 Juhonkylä: Tutkimus pohjoissuomalaisesta Laestadiolaiskylästä. Helsinki: Suomen Kirjallisuuden Seura.

\section{Talonen, Jouko \& Iipo Harjutsalo}

2001 Laestadiolaisuuden monet kasvot. Helsinki: Suomen teologinen instituutti.

\section{Thomas, Paul}

2009 New Religious Movements. - John Lyden (ed), The Routledge Companion to Religion and Film, 214-35. London: Routledge.

\section{Thornham, Sue}

1997 Passionate detachment: an introduction to feminist film theory. London: Arnold

\section{Tigervall, Carina}

2003 Tigerns avklippta morrhår: Vi och de andra $i$ den nya svenska filmen anno 2000. Umeå: Umeå University.

\section{Wentin, Erik}

1986 (1963) Laestadianismen i svenska Österbotten. Villmanstrand: EteläSaimaan kustannus.

\section{Willis, Sharon}

1997 High Contrast: Race and Gender in Contemporary Hollywood Film. Durham: Duke University Press.

\section{Wright, Rochelle}

1998 The Visible Wall Jews and Other Ethnic Outsiders in Swedish Film. Uppsala: Acta Universitatis Upsaliensis. 